\title{
Using SWAT Model to Determine Runoff, Sediment Yield in Maroon-Dam Catchment
}

\author{
Nasrin Zalaki-Badil ${ }^{1}$, Saeid Eslamian ${ }^{2}$, Gholam-Abbas Sayyad ${ }^{3}$, Seyed-Ebrahim Hosseini ${ }^{4}$, \\ Mehdi Asadilour ${ }^{5}$, Kaveh Ostad-Ali-Askari ${ }^{6}$, Vijay P. Singh ${ }^{7}$, Shahide Dehghan ${ }^{8}$ \\ ${ }^{I}$ Department of soil science, Shahid chamran university of Ahvaz, Iran. \\ ${ }^{2}$ Department of Water Engineering, Isfahan University of Technology, Isfahan, Iran. \\ ${ }^{3}$ Department of Soil Science, Faculty of Agriculture, Shahid Chamran University of Ahvaz, Ahvaz, Iran. \\ ${ }^{4}$ Khuzestan Water and Power Authority (KWPA), Ahvaz, Iran. \\ ${ }^{5}$ Department of irrigation, Ahvaz branch, Islamic Azad University, Ahvaz, Iran. \\ ${ }^{6}$ Department of Civil Engineering, Isfahan (Khorasgan) Branch, Islamic Azad University, Isfahan, Iran. \\ ${ }^{7}$ Department of Biological and Agricultural Engineering \& Zachry Department of Civil Engineering, Texas A \\ and M University, 321 Scoates Hall, 2117 TAMU, College Station, Texas 77843-2117, U.S.A.
}

${ }^{8}$ Department of Geography, Najafabad Branch, Islamic Azad University, Najafabad, Iran.

\begin{abstract}
*Corresponding Author: Dr. Kaveh Ostad-Ali-Askari., Department of Civil Engineering, Isfahan (Khorasgan) Branch, Islamic Azad University, University Blvd, Arqavanieh, Jey Street, P.O.Box: 81595158 Isfahan, Iran. E-mail: Koa.askari@khuisf.ac.ir
\end{abstract}

\begin{abstract}
The Soil and water assessment tool (SWAT) model is a flexible, physically distributed model was developed as a river basin scale to quantify and predict runoff and transportation from watersheds and river basins. The semi-automated Sequential Uncertainty Fitting (SUFI2) calibration process built in SWAT calibration and uncertainty program (SWAT-CUP) were used to calibrate the model parameters using time series of flow and sediment load data of 1994 to 2002 and validated with the observed data from years 2002 to 2007. The performance of the model was evaluated using statistical and graphical methods to assess the capability of the model in simulating the runoff and sediment yield for the study area. The result showed relatively good fitness between measured and simulated discharge and sediment. The Nash Sutcliffe efficiency and R2 were nearly $70 \%$ for discharge and $76 \%$ for sediment load. Overall, simulation of runoff and sediment is satisfactory by using the SWAT model.
\end{abstract}

Keywords: Runoff; Sediment Yield; Calibration; Validation; SWAT-CUP; SUFI2

\section{INTRODUCTION}

Soil erosion is a worldwide environmental problem that degrades soil productivity and water quality, causes sedimentation in reservoirs, and increases the probability of floods [1-9].

Sediment transport rate is affected by hydrological as well as hydraulic characteristics. Since the former cannot be adequately taken into account quantitatively, a high degree of accuracy in sediment load computations cannot be expected [2-3]. Watershed management programs frequently fail to reduce sediment yield because either the physical nature of the problem is not properly diagnosed or the economic and cultural conditions leading to accelerated erosion are not addressed and erosion control practices are abandoned as soon as government subsidies are removed (Gregory and Fan, 1998). Besides, the development of a comprehensive sediment yield model requires substantial funding, extensive time and expertise, which are often unavailable in developing countries [4-6].

The soil and water assessment tool (SWAT) is a physically based, continuous time model, developed by Dr. Jeff Arnold for the USDA-ARS (Agricultural Research Service) (Arnold et al., 2001), mostly used to predict the impact of land management practices on water, sediment, and nutrient yields over 
long periods of time [7-9]. SWAT model has been used extensively to access water quality and quantity changes in the catchment responding to agricultural management across the US, Canada and other European countries [10-15]

In previous studies, it was difficult to account for sediment yield deposition the catchment and to model the individual erosion processes. Therefore, this study aimed at assessing the suitability of SWAT2005 model [16-18] as one of the watershed erosion models in simulating inflow and sediment yield in Maroon Dam mountainous catchment. The model was used to assess its suitability in modeling sediment yield in the data scarce catchments, located in south western of IRAN.

\section{Methods AND Material}

\subsection{Study Area}

The studied watershed, named Maroon Dam (Idanak station), is in south west of IRAN (Figure 1). The area of the watershed is about 2700 ha and located in a Semi- arid climatic region. Annual average precipitation is approximately $639.0 \mathrm{~mm}$ concentrated between November and May. Mean annual temperature is $23^{\circ} \mathrm{C}$.

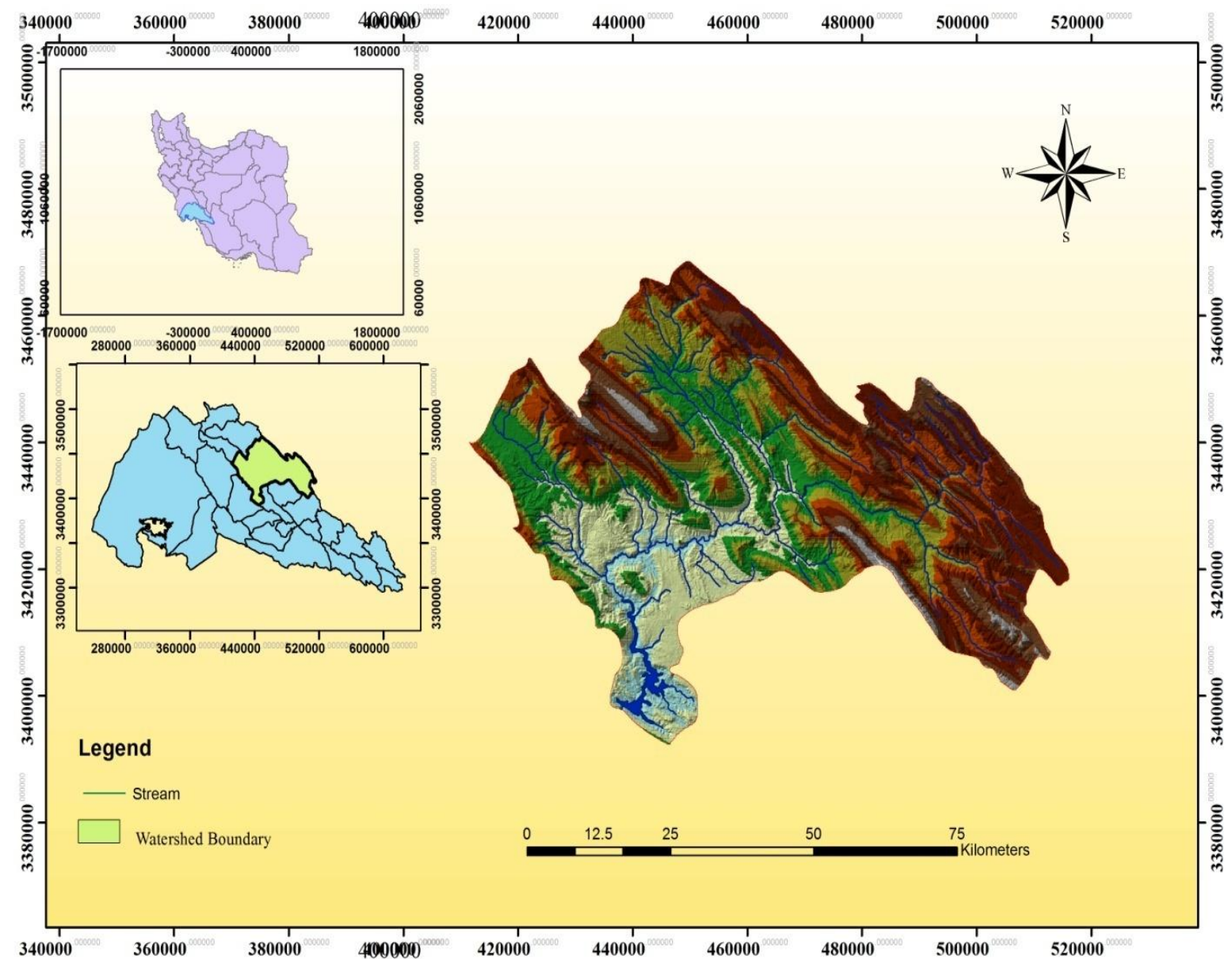

Figure1. Research site: Dam Maroon watershed

\subsection{SWAT Input Data}

The basic input data included the digital elevation model (DEM), land use, soil maps and climate data. Data has been collected and processed for daily rainfall, runoff and sediment discharge, and maximum and minimum temperature for the watershed during 1987 to 2006.

The SWAT2005 was used to delineate the boundaries of the entire study area and its sub-basins. The model was calibrated using data in the catchment of Maroon Dam. During the simulation process the inflow and sediment yield was calibrated and then validated. 


\section{RESULTS AND DISCUSSION}

Model calibration and validation are indispensable for simulation process, which are used to assess model prediction results. Calibration was performed by comparing the simulated and observed surface runoff. After achieving a reasonable runoff data, the same parameters were used for calibration of the sediment and further for validation.

River sediment yields were estimated primarily by quantifying soil losses from HRU's with the

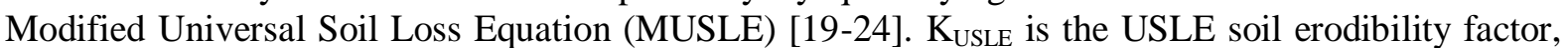
$\mathrm{C}_{\mathrm{USLE}}$ is the USLE cover and management factor, $\mathrm{P}_{\mathrm{USLE}}$ is the USLE support practice factor and CFRG is the coarse fragment factor [25-32].

The available measurements of flows and sediments were used for comparison with the predicted results in order to test the SWAT simulation efficiency. Calibration took place in monthly basis at Idanak Station, where inflow data is existed from 1994 to 2006 and sediment measurement data from 1995 to 2006. Figures 2 and 3 represents the graphical comparison between predicted and observed flows and sediment yields in Idanak during calibration and validation periods [33-59].
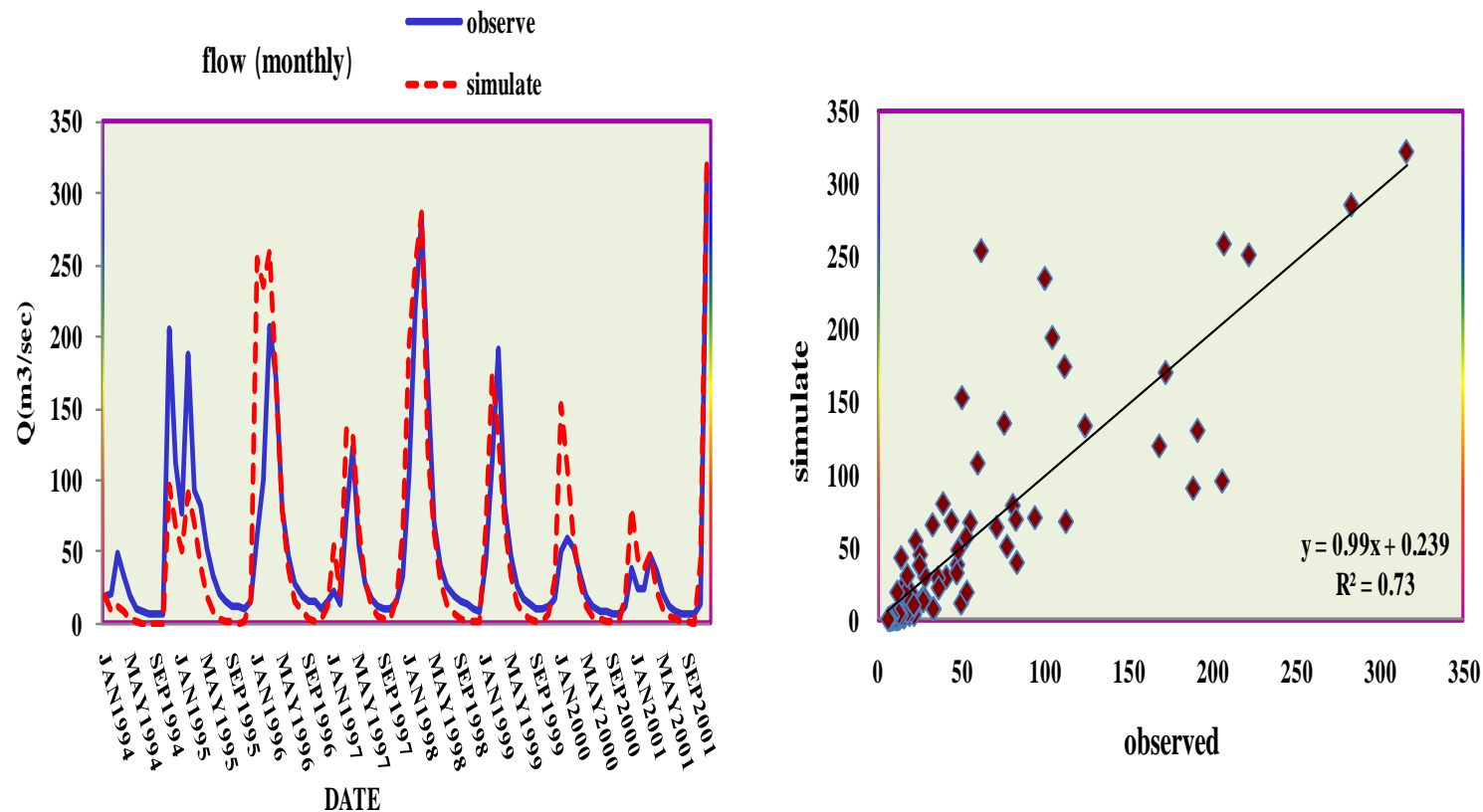

Figure2. Observed and predicted flows in Idanak Station during calibration period
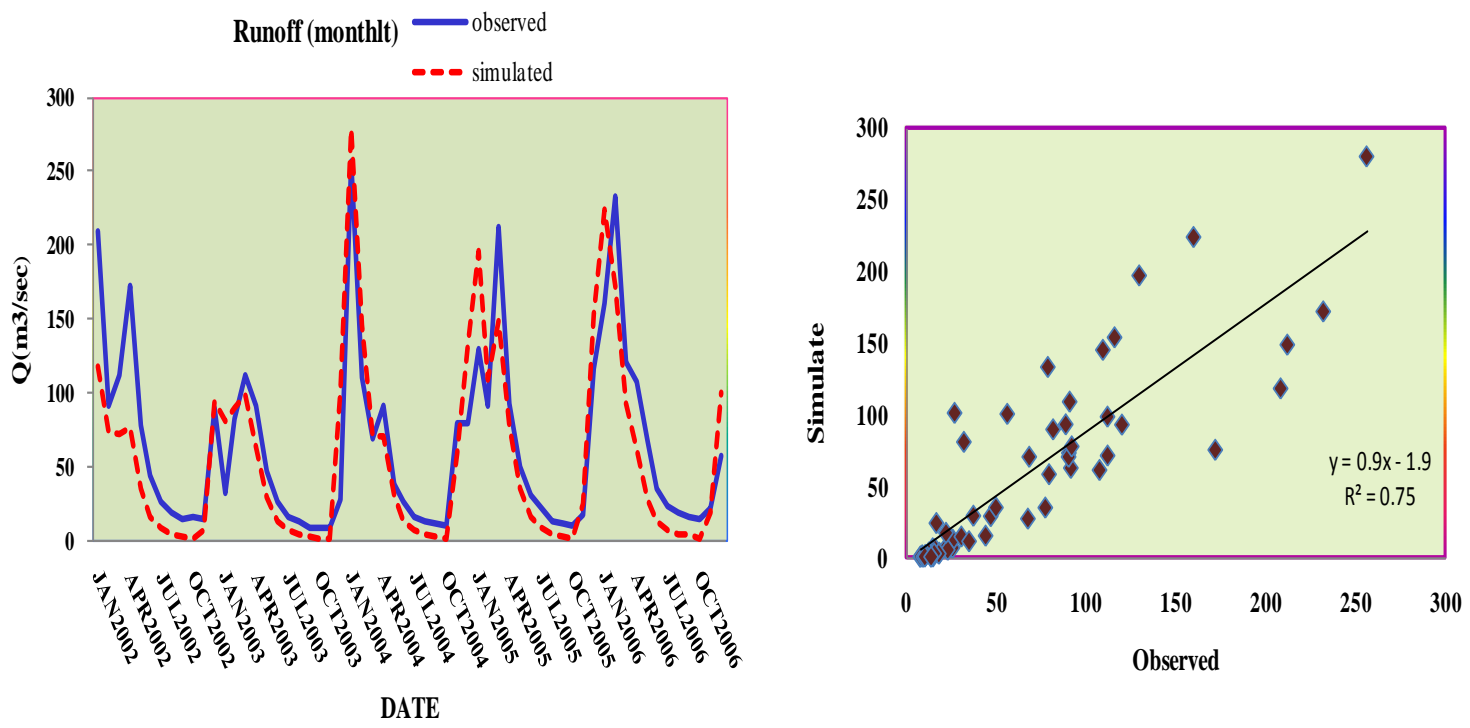

Figure3. Observed and predicted flows in Idanak Station during validation period 

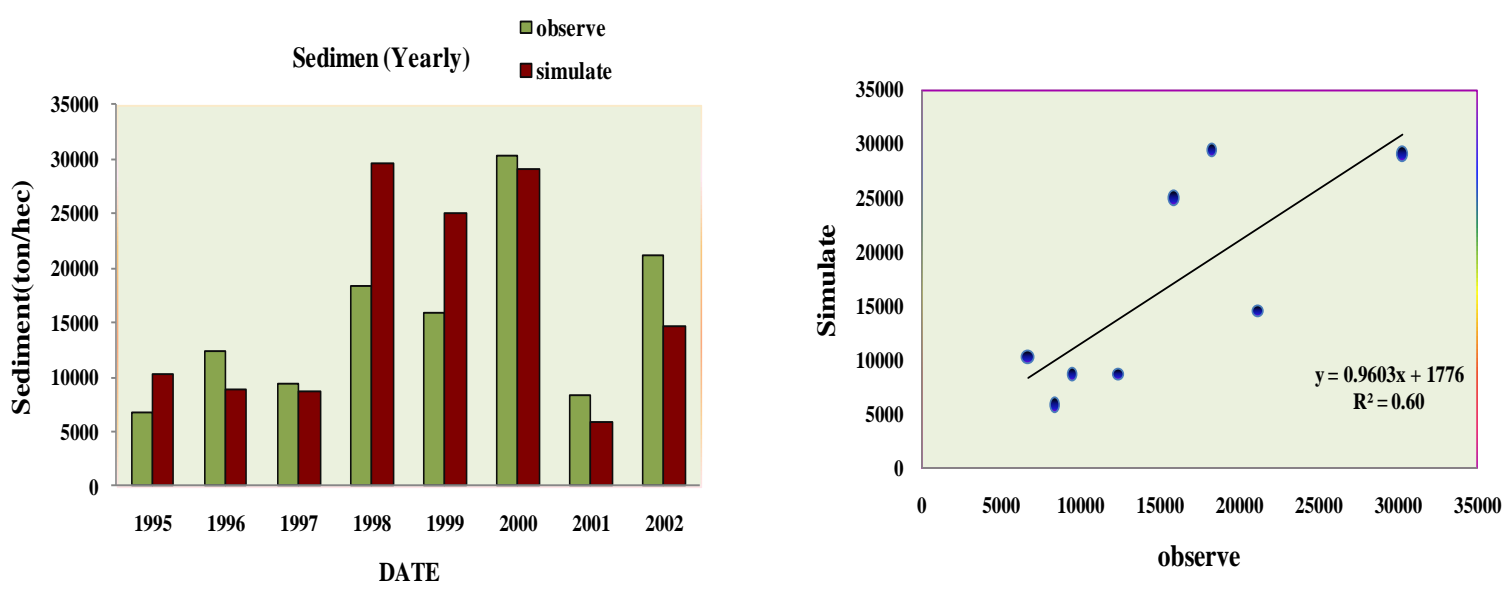

Figure4. Observed and predicted sediment yields in Idanak Station during calibration period
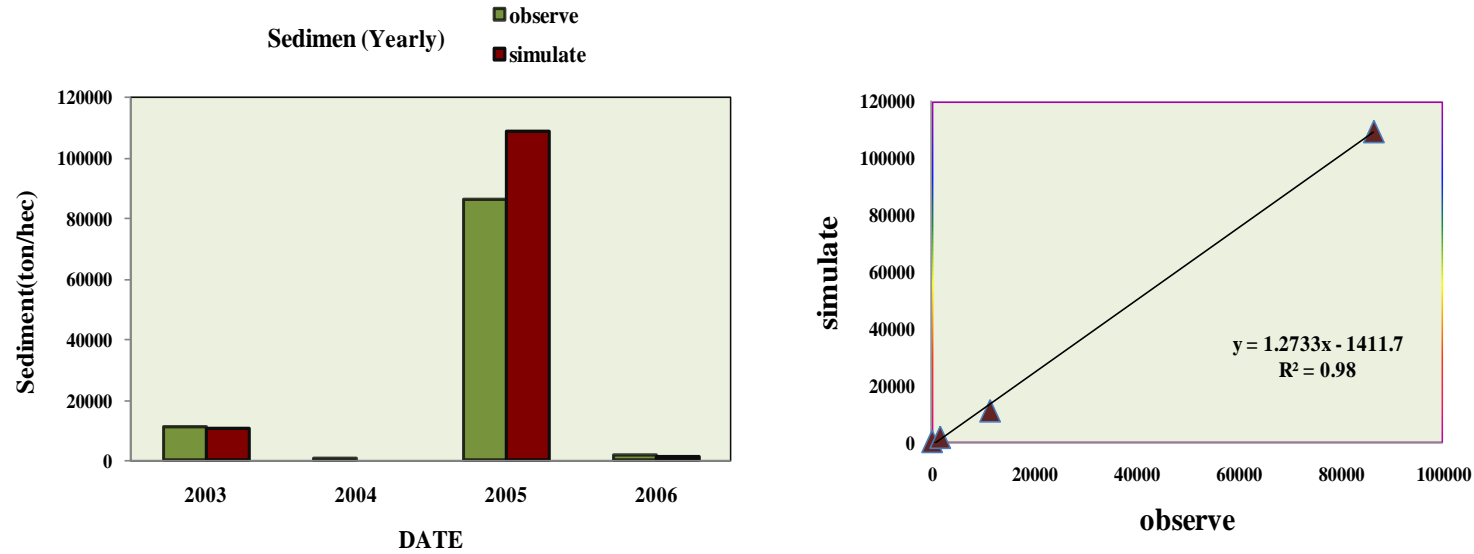

Figure5. Observed and predicted sediment yields in Idanak Station during validation period

Different values appeared between the simulated and observed monthly-runoff during the simulation for 1994-2001. The difference might be explained by the measured errors in runoff data, and system errors of SWAT [60-79]. After reasonable parameter calibration, in validation process, simulated monthly-runoff was in the range of the observed values (Figure.3) [80-98].

The correlation coefficient and Nash-Sutcliffe coefficient reached 0.75 and 0.70 respectively, which showed the validity of the simulation (Figure.4). Also the correlation coefficient in calibration and validation process during sediment load simulation reached to 0.60 and 0.98 respectively (Figure.5) [99-124].

\section{CONCLUSION}

In this study SWAT was used to simulate inflow and sediment yield in the Maroon Dam watershed in south west of Iran. Simulated flow and sediment yields were generally in agreement with measured data.

The Auto-calibration Tool in Arc SWAT provides a user-friendly method for specifying various inputs including calibration parameters and desired widths of uncertainty confidence intervals. It also facilitates specification of measured data sets and the desired output parameters and objective functions. The text-based summaries from the three components of the Tool can be used to determine the optimal parameter set for calibration purposes, parameter sensitivity ranges and corresponding objective function ranges. Time series graphs, with or without parameter and model uncertainty bounds, can be created from additional output files to facilitate comparison between the amount of variation in the model results and the measured data.

\section{REFERENCES}

[1] Abbaspour K C, C A Johnson, M. Th. Van Genuchten, 2004. Estimating uncertain flow and transport parameters using a sequential uncertainty fitting procedure. Vadose Zone 3: 1340-1352. 
[2] Christianson C, 1981. "Soil Erosion and sedimentation in semi-arid Tanzania". PhD Thesis. Scandinavian Institute of African Studies, Uppsala and Department of Physical Geography, University of Stockholm. Garde R J, Rangaraju K G, 2000.

[3] FitzHugh T W, Mackay DS, 2000. Impacts of input parameter spatial aggregation on an agricultural nonpoint source pollution model. Journal of Hydrology 236: 35-53.

[4] Gregory L M, Jiahua Fan, 1998. Design and Management of Dams, Reservoirs, and Watersheds for Sustainable Use. Reservoir Sedimentation Handbook. McGraw-Hill companies, Inc.

[5] Mehmet C Demirel, Anabela Venancia, Ercan Kahya, 2009. Flow forecast by SWAT model and ANN in Pracana basin, Portugal. Advances in Engineering Software, 40: 467-473.

[6] Mulengera, M K, 1999. "Estimating the USLE-Soil Erodibility factor in developing tropical countries". Trop. Agric. Trinidad), 76(1): 17-22.

[7] Neitsch S L, Arnold J G, Kiniry J R, Williams J R, K W King, 2005a. Soil and water assessment tool: Theoretical documentation. Blackland Research Center, Texas Agricultural Experiment Station, 494 p.

[8] Neitsch S L, Arnold J G, Kiniry J R, Williams J R, K W King. 2005a. Soil and Water Assessment Tool User's Manual Version 2000, Texas Agricultural Experiment Station, 494p.

[9] Ouyung D, Bratholic J. 2001. "Web-based GIS Application for Soil Erosion Prediction.” Pricceedings of an International Symposium. Soil Erosion Research for the 21st Century Honolulu, HI. Jan. 3-5, 2001. Institute of Water Research, Michigan State University.

[10] Pandy V K, Sudhindra N. (2005). Modeling of Agricultural watershed usinf RS and GIS Biosystem Eng. 90(3), 331-347.

[11] Plus M, La Jeunesse I, Bouraoui F, Zaldı'var, J M, Chapelle A, Lazure P, 2006. Modelling water discharges and nitrogen inputs into a Mediterranean lagoon- Impact on the primary production. Ecological Modelling 193, 69-89.

[12] Ostad-Ali-Askari, K., Shayannejad, M. 2015, Study of sensitivity of Autumnal wheat to under irrigation in Shahrekord, Shahrekord City, Iran. International Journal of Agriculture and Crop Sciences, 8 (4), $602-605$.

[13] Shayannejad, M., Akbari, N., Ostad-Ali-Askari, K. 2015, Study of modifications of the river physical specifications on muskingum coefficients, through employment of genetic algorithm. International Journal of Development Research, 5(3), 3782-3785.

[14] Ostad-Ali-Askari, K., Shayannejad, M. 2015, The Reviews of Einstein's Equation of Logarithmic Distribution Platform and the Process of Changes in the Speed Range of the Karkheh River, Khuzestan province, Iran. International Journal of Development Research, 5(3), 3786-3790.

[15] Ostad-Ali-Askari, K., Shayannejad, M., Ghorbanizadee-Kharazi, H. 2015, Assessment of artificial neural network performance and exponential regression in prediction of effective rainfall, International Journal of Development Research, 5(3), 3791-3794.

[16] Shayannejad, M. Akbari, N. and Ostad-Ali-Askari, K. 2015, Determination of the nonlinear Muskingum model coefficients using genetic algorithm and numerical solution of the continuity. Int. J. of Science: Basic and Applied Research, 21(1), 1-14.

[17] Ostad-Ali-Askari, K., Shayannejad, M. 2015, the Study of Mixture Design for Foam Bitumen and the Polymeric and Oil Materials Function in Loose Soils Consolidation. Journal of Civil Engineering Research, 5(2), 39-44. DOI: 10.5923/j.jce.20150502.04

[18] Sayedipour, M., Ostad-Ali-Askari, K., Shayannejad, M. 2015, Recovery of Run off of the Sewage Refinery, a Factor for Balancing the Isfahan-Borkhar Plain Water Table in Drought Crisis Situation in Isfahan Province-Iran. American Journal of Environmental Engineering, 5(2): 43-46. DOI: 10.5923/j.ajee.20150502.02

[19] Ostad-Ali-Askari, K., Shayannejad, M. 2015, Developing an Optimal Design Model of Furrow Irrigation Based on the Minimum Cost and Maximum Irrigation Efficiency. International Bulletin of Water Resources \& Development, 3(2), 18-23.

[20] Ostad-Ali-Askari, K., Shayannejad, M. 2015, Presenting a Mathematical Model for Estimating the Deep Percolation Due to Irrigation. International Journal of Hydraulic Engineering, 4(1), 17-21. DOI: 10.5923/j.ijhe.20150401.03.

[21] Ostad-Ali-Askari, K., Shayannejad, M. 2015, Usage of rock fill dams in the HEC-RAS software for the purpose of controlling floods. American Journal of Fluid Dynamics, 5(1), 23-29. DOI: 10.5923/j.ajfd.20150501.03.

[22] Raeisi-Vanani, H., Soltani Todeshki, A. R., Ostad-Ali- Askari, K., Shayannejad, M. 2015, The effect of heterogeneity due to inappropriate tillage on water advance and recession in furrow irrigation. Journal of Agricultural Science, 7(6), 127-136. 
[23] Soltani-Todeshki, A. R., Raeisi-Vanani, H., Shayannejad, M., Ostad-Ali-Askari, K. 2015, Effects of magnetized municipal effluent on some chemical properties of soil in furrow irrigation. International Journal of Agriculture and Crop Sciences, 8(3), 482-489.

[24] Ostad-Ali-Askari, K., Shayannejad, M. 2015, Optimal design of pressurized irrigation laterals installed on sloping land. International Journal of Agriculture and Crop Sciences, ISSN 2227-670X. 8(5), 792-797.

[25] Ostad-Ali-Askari K, Shayannejad M, Eslamian S, Navab-Pour B. 2016, Comparison of solution of SaintVenant equations by characteristics and finite difference methods for unsteady flow analyzing in open channel. International Journal of Hydrology Science and Technology, 6(3), 9-18.

[26] Ostad-Ali-Askari K, Shayannejad M, Eslamian S, et al. 2017, Deficit Irrigation: Optimization Models. Management of Drought and Water Scarcity. Handbook of Drought and Water Scarcity, Taylor \& Francis Publisher, USA. Vol. 3. $1^{\text {th }}$ Edition, pp: 373-389.

[27] Raeisi Vanani H, Shayannejad M, Soltani Tudeshki A.R, Ostad-Ali-Askari K, Eslamian S, et al. 2017 , Development of a new method for determination of infiltration coefficients in furrow irrigation with natural non-uniformity of slope. Sustain. Water Resour. Manag. 3(2): 163-169.

[28] Shojaei N, Shafaei-Bejestan M, Eslamian S, Marani-Barzani M, P. Singh V, Kazemi M, Ostad-Ali-Askari K. 2017, Assessment of Drainage Slope on the Manning Coarseness Coefficient in Mountain Area. International Journal of Constructive Research in Civil Engineering (IJCRCE), 3(1): 33-40.

[29] Bahmanpour H, Awhadi S, Enjili J, Hosseini S.M, Raeisi Vanani H, Eslamian S, Ostad-Ali-Askari K. 2017, Optimizing Absorbent Bentonite and Evaluation of Contaminants Removal from Petrochemical Industries Wastewater. International Journal of Constructive Research in Civil Engineering (IJCRCE), 3(2): 34-42.

[30] Shayannejad M, Eslamian S, Gandomkar A, Marani-Barzani M, Amoushahi-Khouzani M, Majidifar Z, Rajaei-Rizi F, Kazemi M, P. Singh V, Dehghan SH, Shirvani-Dastgerdi H.R, Norouzi H, Ostad-Ali-Askari K. 2017, A Proper Way to Install Trapezoidal Flumes for Measurements in Furrow Irrigation Systems. International Journal of Research Studies in Agricultural Sciences (IJRSAS), 3(7): 1-5.

[31] Dehghan Sh, Kamaneh S.A.A., Eslamian S, Gandomkar A, Marani-Barzani M, Amoushahi-Khouzani M, Singh V.P., Ostad-Ali-Askari K. 2017, Changes in Temperature and Precipitation with the Analysis of Geomorphic Basin Chaos in Shiraz, Iran. International Journal of Constructive Research in Civil Engineering (IJCRCE), 3(2): 50-57.

[32] Ostad-Ali-Askari K, Shayannejad M. 2016, FLOOD ROUTING IN RIVERS BY MUSKINGUM'S METHOD WITH NEW ADJUSTED COEFFICIENTS. International Water Technology Journal, IWTJ, 6(3): 189-194.

[33] Ostad-Ali-Askari K, Shayannejad M, Ghorbanizadeh-Kharazi H. 2017, Artificial Neural Network for Modeling Nitrate Pollution of Groundwater in Marginal Area of Zayandeh-rood River, Isfahan, Iran. KSCE Journal of Civil Engineering, 21(1):134-140. Korean Society of Civil Engineers. DOI 10.1007/s12205-016-0572-8.

[34] Raeisi-Vanani H, Soltani-Toudeshki A.R, Shayannejad M, Ostad-Ali-Askari K, Ramesh A, Singh V.P., Eslamian S. 2017, Wastewater and Magnetized Wastewater Effects on Soil Erosion in Furrow Irrigation. International Journal of Research Studies in Agricultural Sciences (IJRSAS), 3(8): 1-14. http://dx.doi.org/10.20431/2454-6224.0308001.

[35] Raeisi-Vanani H, Shayannejad M, Soltani-Toudeshki A.R, Arab M.A, Eslamian S, Amoushahi-Khouzani M, Marani-Barzani M, Ostad-Ali-Askari K. 2017, A Simple Method for Land Grading Computations and its Comparison with Genetic Algorithm (GA) Method. International Journal of Research Studies in Agricultural Sciences (IJRSAS), 3(8): 26-38.

[36] Mohieyimen P, Eslamian S, Ostad-Ali-Askari K, Soltani M. 2017, Climate Variability: Integration of Renewable Energy into Present and Future Energy Systems in Designing ResidentialBuildings. International journal of Rural Development, Environment and Health Research (IJREH), 1(2): 18-30.

[37] Gargouri-Ellouze, E. and Eslamian, S. 2014, Application of Copulas in Hydrology: Geomorphological Instantaneous Unit Hydrograph and Intensity Index of Infiltration Frequency, in Handbook of Engineering Hydrology, Ch. 1, Vol. 2: Modeling, Climate Changes and Variability, Ed. By Eslamian, S., Francis and Taylor, CRC Group, USA, 1-18.

[38] Mujere, N. and Eslamian, S. 2014, Climate Change Impacts on Hydrology and Water Resources, in Handbook of Engineering Hydrology, Ch. 7, and Vol. 2: Modeling, Climate Changes and Variability, Ed. By Eslamian, S., Francis and Taylor, CRC Group, USA, 113-126.

[39] Farzaneh, M. R., Eslamian, S. and Mirnezami, S. J. E. 2014, Climate Change: Uncertainty, Impact, and Adaptation, in Handbook of Engineering Hydrology, Ch. 8, and Vol. 2: Modeling, Climate Changes and Variability, Ed. By Eslamian, S., Francis and Taylor, CRC Group, USA, 127-146. 
[40] Goodarzi, E. and Eslamian, S. 2014, Dam Risk and Uncertainty, in Handbook of Engineering Hydrology, Ch. 9, and Vol. 2: Modeling, Climate Changes and Variability, Ed. By Eslamian, S., Francis and Taylor, CRC Group, USA, 147-171.

[41] Fakhri, M., Dokohaki, H., Eslamian, S., Fazeli Farsani, I. and Farzaneh, M. R. 2014, Flow and Sediment Transport Modeling in Rivers, in Handbook of Engineering Hydrology, Ch. 13, Vol. 2: Modeling, Climate Changes and Variability, Ed. By Eslamian, S., Francis and Taylor, CRC Group, USA, 233-275.

[42] Matouq, M., Al-Bilbisi, H., El-Hasan, T. and Eslamian, S. 2014, GIS Applications in a Changing Climate, in Handbook of Engineering Hydrology, Ch. 15, and Vol. 2: Modeling, Climate Changes and Variability, Ed. By Eslamian, S., Francis and Taylor, CRC Group, USA, 297-312.

[43] Noor Islam, S., Gnauck, A., Voigt, H.-J. And Eslamian, S., 2014, Hydrological Changes in Mangrove Ecosystems, in Handbook of Engineering Hydrology, Ch. 18, Vol. 2: Modeling, Climate Changes and Variability, Ed. By Eslamian, S., Francis and Taylor, CRC Group, USA, 353-373.

[44] Kałuża, T. and Eslamian, S. 2014, Impact of the Development of Vegetation on Flow Conditions and Flood Hazards, in Handbook of Engineering Hydrology, Ch. 21, Vol. 2: Modeling, Climate Changes and Variability, Ed. By Eslamian, S., Francis and Taylor, CRC Group, USA, 415-449.

[45] Rahman, A., Haddad, Kh. and Eslamian, S., 2014, Regional Flood Frequency Analysis, 2014, in Handbook of Engineering Hydrology, Ch. 22, and Vol. 2: Modeling, Climate Changes and Variability, Ed. By Eslamian, S., Francis and Taylor, CRC Group, USA, 451-469.

[46] Vafakhah, M. and Eslamian, S. 2014, Regionalization of Hydrological Variables, in Handbook of Engineering Hydrology, Ch. 23, and Vol. 2: Modeling, Climate Changes and Variability, Ed. By Eslamian, S., Francis and Taylor, CRC Group, USA, 471-499.

[47] Chowdhury, R. K. And Eslamian, S. 2014, Statistical Parameters Used for Assessing Hydrological Regime, in Handbook of Engineering Hydrology, Ch. 26, Vol. 2: Modeling, Climate Changes and Variability, Ed. By Eslamian, S., Francis and Taylor, CRC Group, USA, 537-551.

[48] Mujere, N. and Eslamian, S. 2014, Impact of Urbanization on Runoff Regime, Chowdhury, R. K. and Eslamian, S. 2014; Statistical Parameters Used for Assessing Hydrological Regime, in Handbook of Engineering Hydrology, Ch. 29, Vol. 2: Modeling, Climate Changes and Variability, Ed. By Eslamian, S., Francis and Taylor, CRC Group, USA, 605-615.

[49] Noor Islam, S., Gnauck, A., Voigt, H.-J. And Eslamian, S., 2014, Hydrological Changes in Mangrove Ecosystems, in Handbook of Engineering Hydrology, Ch. 18, Vol. 2: Modeling, Climate Changes and Variability, Ed. By Eslamian, S., Francis and Taylor, CRC Group, USA, 353-373.

[50] Akhavan S., Abedi-Koupai, J, Mousavi, S, F., Afyuni, M., Eslamian, S. S. and K. C. Abbaspour, 2010, Application of SWAT model to investigate nitrate leaching in Hamadan-Bahar Watershed, Iran, Agriculture, Ecosystems and Environment, Vol. 139, 675-688.

[51] Bazrkar, M.H., Zeyaei, R., and Eslamian, S.S., 2013, Eutriphication: A Water Body's Problem, International Symposium on Eco-hydrology, Biotechnology and Engineering: Towards the Harmony Between Bio-geosphere and Society on the Basis of Long Term Ecosystem Research, September 16-22, Lodz, Poland.

[52] Eslamian, F. and Eslamian S., 2014, Water Pollution Control Using Low-Cost Natural Wastes, in Handbook of Engineering Hydrology, Ch. 25, Vol. 3: Environmental Hydrology and Water Management, Ed. By Eslamian, S., Francis and Taylor, CRC Group, USA, 485-499.

[53] Malekian, R., Abedi-Koupai, J., Eslamian, S. S., Mousavi, S. F., Abbaspour, K. C. and M. Afyuni, 2011, Ion-exchange process for ammonium removal and release using natural Iranian zeolite, Applied Clay Science, Vol. 51, 323-329.

[54] Eslamian, S. S. and R. Nazari, 2002, Economic Evaluation of an Iranian Water Resources Project, Third Conference on Agriculture and Natural Resources, Iran and Russia, Moscow.

[55] Abedi-Koupai, J., Eslamian, S.S. and Khaleghi, M., 2013, Performance of Sand Filters including the tire powder for in lining of underground drains, The Journal of Science and Technology of Agriculture and Natural Resources, Water and Soil Science, Vol. 16, No. 62, 193-202.

[56] Abedi-Koupai , J., Eslamian, S. S., Gohari , S. A., and R. Khodadadi, 2011, Evaluation of Mechanical Properties of Water Conveyance Concrete Canals Incorporating Nano Pozzolan of Wheat Ash Sheath, The Journal of Science and Technology of Agriculture and Natural Resources, Water and Soil Science, Vol. 14, No. 54, 39-52.

[57] Akhavan, S., Abedi-Koupai, J., Mousavi, S. F., Abbaspour, K., Afyuni, M. and S. S. Eslamian, 2010, Estimation of Blue Water and Green Water Using SWAT Model in Hamadan-Bahar Watershed, The Journal of Science and Technology of Agriculture and Natural Resources, Water and Soil Science, Vol. 14, No. 53, 9-23. 
[58] Saadati, S., Soltani, S. and S. S. Eslamian, 2009, Statistical analysis of return period of drought conditions in Isfahan province using the Standardized Precipitation Index, Journal of Range and Watershed Management, Iranian Journal of Natural Resources, Vol. 62, No. 1, 249-261.

[59] Eslamian, S. S. and A. Mehrabi, 2005, Identifying emprical equations for time of concentration in mountainous watershed, Journal of Agricultural Sciences and Natural Resources, Vol.12, No. 5, 36-45.

[60] Eslamian S. S., Zarei A. and A. Abrishamchi, 2004, Regional estimation of low flows for Mazandaran River basin, Journal of Science and Technology of Agriculture and Natural Resources, Vol. 8, No. 2., 2738.

[61] Nosrati, K., Mohseni-saravi M., Eslamian S. S., Sharifi, F. and M. Mahdavi, 2004, Determination of Homogeneous regions for frequency analysis of low flows, Iranian Natural Resources Journal, Vol. 57, No. 1., 45-58.

[62] Eslamian, S. S. and S. Chavoshi-Boroujeni, 2003, Application of L-moments theory for flood frequency analysis of Iranian central catchments, Journal of Science and Technology of Agriculture and Natural Resources, Vol. 7, No. 1, 1-17.

[63] Kiaheirati, J., Eslamian, S. S. and H. Khademi, 2002, Evaluating performance of flood spreading for groundwater Table artificial recharge, Iranian Natural Resources Journal, Vol. 55, No. 2., 159-171.

[64] Kiaheirati, J., Khademi, H., Eslamian, S. S. and A. H. Charkhabi, 2002, Role of deposited sediments in changing physical-chemical properties of soils in the Moghar floodwater spreading system, Journal of Agricultural Sciences and Natural Resources, Vol. 9, No. 2., 27-40.

[65] Izadbakhsh, M. A., Eslamian, S. S. and S. F. Mousavi, 2001, Maximum-daily mean-discharge predicting models using physiographic characteristics of catchments in some western Iran watersheds, Journal of Science and Technology of Agriculture and Natural Resources, Vol. 5, No. 2, 1-13.

[66] Gazavi, G. and S. S. Eslamian, 2001, Comparison of calcareous and non-calcareous catchments in view of stream surface runoff, Journal of Agricultural Sciences and Natural Resources, Vol. 7, No. 4, 3-14.

[67] Eslamian, S. S., Salimi V. and S. Chavoshi-Boroujeni, 2000, Developing an empirical model for the estimation of peak discharge in some catchments in western Iran, Journal of Science and Technology of Agriculture and Natural Resources, Vol. 4, No. 2, 1-12.

[68] Chavoshi-Boroujeni, S. and S. S. Eslamian, 1999, Regional flood frequency analysis in Zayandehrood watershed using the hybrid method, Journal of Science and Technology of Agricultural and Natural Resources, Vol. 3, No. 3, 1-12.

[69] Mousavi, S. F., Jamshid nezhad-Anbarany, J., Eslamian, S. S. and N. Rostam-Afshar, 1999, Estimation of runoff coefficients for the Caspian Sea catchments, Journal of Science and Technology of Agriculture and Natural Resources, Vol. 3, No. 2, 1-19.

[70] Taebi, A., Eslamian, S. S. and M. Vashtani, 2000, Evaluation of Urban Runoff Quality Models, First Regional Conference on Water Balance, Khuzestan Water and Power Authority, Ahwaz, Iran, 393-402.

[71] Taebi, A., Eslamian, S. S. and M. Vashtani, 1999, Evaluation of Urban Runoff Quality Models, First Regional Conference on Water Balance, Khuzestan Water and Power Authority, Ahwaz, Iran, 393-402.

[72] Taebi, A., Eslamian, S. S. and M. Vashtani, 2000, Evaluation of Urban Runoff Quality Models, First Regional Conference on Water Balance, Khuzestan Water and Power Authority, Ahwaz, Iran, 393-402.

[73] Hosseini, S. Z., Heidarpour, M., Eslamian, S. S., 2012, Effect of Conductor of Blades Submerged Weir discharge coefficient triangle with vertex angle of 45 degrees, Ninth International Conference on River Engineering, Ahvaz.

[74] Bahmani, R., Eslamian, S. S., Naderi-Bani, M., Fahhian F., 2012, Investigating Maximum Rainfall Intensity on Peak Discharge using IDF curves and HEC-HMS model, Ninth International Conference on River Engineering, Ahvaz.

[75] Fakhri, M., Eslamian, S. S., Rostamian, R., and Fazeli, I, 2012, A Review on Erosion and Sediment Transfer Models with Emphasis on Sediment Modeling of Beheshtabad Sub-basin, North Karoon, using SWAT Model, Ninth International Conference on River Engineering, Ahvaz.

[76] Amini Nezhad, S. M. and S. S. Eslamian, 2012, Toward a more Holistic Perspective of Soil Erosion, Dust Haze Events and Interaction between Aeolian and Fluvial Transport Processes, the 1st International Congress on Dust Haze and Combating its Adverse Effects, Ahvaz, Iran.

[77] Chavoshi, S., S. Eslamian. 1999. Catchments group delineation using different methods of homogeneity. Proceeding of the First Regional Conference on Water Balance, Ministry of Energy of Iran, Bureau of Water and Energy of Khoozestan, Ahvaz, Iran.

[78] Eslamian, S. S., 2009, Basin Ecology and Environment (BEE), International Journal of Ecological Economic \& Statistics, Ed., Special Issue Volume, CESER, Vol. 13, No. W09, 1-99.

International Journal of Research Studies in Agricultural Sciences (IJRSAS)

Page | 38 
[79] Gohari, A., Zareian, M. J., Eslamian, S., Nazari, R. 2017, Interbasin Transfers of Water: Zayandeh-Rud River Basin, Ch. 32 in Handbook of Drought and Water Scarcity, Vol. 2: Environmental Impacts and Analysis of Drought and Water Scarcity, Ed. by Eslamian S. and Eslamian F., Francis and Taylor, CRC Press, USA, 619-630.

[80] Goodarzi, E., Ziaei, L. and Eslamian, S., 2015, Recycled Water in Basin and Farm Scales, Urban Water Reuse Handbook, Ch. 65, Ed. By Eslamian, S., Taylor and Francis, CRC Group, 855-858.

[81] Kouhestani, S., Eslamian, S.S., Abedi-Koupai, J. and Besalatpour, A.A., 2016. Projection of climate change impacts on precipitation using soft-computing techniques: A case study in Zayandeh-rud Basin, Iran. Global and Planetary Change, No. 144, 158-170.

[82] Fathian, F., Dehghan, Z.., Eslamian, S., 2016, Evaluating the impact of changes in land cover and climate variability on streamflow trends (case study: eastern subbasins of Lake Urmia, Iran), J. Hydrology Science and Technology, Vol. 6, No. 1, 1-26.

[83] Yousefi, N., Safaee, A., Eslamian, S., 2015, The Optimum Design of Flood Control System Using Multivariate Decision Making Methods (Case Study: Kan River Catchment Basin, Iran), Journal of Flood Engineering, Vol. 6, No. 1, 63-82.

[84] Farshad F., Dehghan, Z., Eslamian, S., H. Bazrkar, 2015, Trends in hydrologic and climatic variables affected by four variations of Mann-Kendall approach in Urmia Lake basin, Iran, Hydrological Sciences Journal, DOI:10.1080/02626667.2014.932911.

[85] Bazrkar, M.H., Tavakoli-Nabavi, E., Zamani, N. and Eslamian, S., 2013, System dynamic approach to hydro-politics in Hirmand transboundary river basin from sustainability perspective, Int. J. Hydrology Science and Technology, Vol. 3, No. 4, 378-398.

[86] Zamani Nuri, A., Farzaneh, M. R., Fakhri, M., Dokoohaki, H., Eslamian, S. and Khordadi, M. J., 2013, Assessment of future climate classification on Urmia Lake basin under effect of climate change, Int. J. Hydrology Science and Technology, Vol. 3, No. 2, 128-140.

[87] Galoie, M., Zenz, G. and Eslamian, S., 2013, Determining the high flood risk regions using a rainfallrunoff modeling in a small basin in catchment area in Austria, Journal of Flood Engineering, Vol. 4, No. (1-2), 9-27.

[88] Galoie, M., Zenz, G. and Eslamian, S., 2013, Application of L-moments for IDF determination in an Austrian basin, Int. J. Hydrology Science and Technology, Vol. 3, No. 1, 30-48.

[89] Gohari, A., Eslamian, S., Abedi-Koupaei, J., Massah-Bavani, A., Wang, D., Madani, K., 2013, Climate change impacts on crop production in Iran's Zayandeh-Rud River Basin. Science of The Total Environment, Vol. 442, 405-419.

[90] Abdolhosseini, M., Eslamian, S., Mousavi, S. F., 2012, Effect of climate change on potential evapotranspiration: a case study on Gharehsoo sub-basin, Iran, Vol. 2 No. 4, 362-372.

[91] Alaghmand, S., Bin Abdullah, R., Abustan, I. and S. Eslamian, 2012, Comparison between capabilities of HEC-RAS and MIKE11 hydraulic models in river flood risk modeling (a case study of Sungai Kayu Ara River basin, Malaysia), International Journal of Environmental Science and Technology, Vol. 2, No. 3, 270-291.

[92] Dhital, Y. P., Kayastha, R. B. and S. S. Eslamian, 2011, Precipitation and discharge pattern analysis: a case study of Bagmati River basin, Nepal, Journal of Flood Engineering, Vol. 2, No. 1, 49-60.

[93] Chavoshi Borujeni, S., Sulaiman, W. N. A. and S. S. Eslamian, 2010, Regional Flood Frequency Analysis Using L-Moments for North Karoon Basin Iran, Journal of Flood Engineering, Vol. 1, No. 1, 67-76.

[94] Eslamian, S. S. and M. J. Khordadi, 2009, Comparing Rainfall and Discharge Trends in Karkhe Basin, Iran, International Journal of Ecological Economics \& Statistics (IJEES), Vol. 15, No. F09, 114-122.

[95] Eslamian, S. S., 2009, Editorial: Frontiers in Ecology and Environment, International Journal of Ecological Economic \& Statistics, Special Issue on Basin Ecology and Environment (BEE), Vol. 13, No. W09, 1-6.

[96] Nosrati, K., Eslamian, S. S., Shahbazi, A., Malekian, A. and M. M. Saravi, 2009, Application of Daily Water Resources Assessment Model for Monitoring Water Resources Indices, International Journal of Ecological Economic \& Statistics, Special Issue on Basin Ecology and Environment (BEE), Vol. 13, No. W09, 88-99.

[97] Matouq, M., Amarneh, I. A., Kloub, N., Badran, O., Al-Duheisat, S. A. and S. S. Eslamian, 2009, Investigating the Effect of Combustion of Blending Jordanian Diesel Oil with Kerosene on Reducing the Environmental Impacts by Diesel Engine, International Journal of Ecological Economic \& Statistics, Special Issue on Basin Ecology and Environment (BEE), Vol. 13, No. W09, 79-87.

[98] Kohansal, M. M., Mohamadi, O., Eslamian, S. S. and M. Kohansal, 2014, Inter-basin Transfer and Saving Uremia Lake by Sustainable Development Approach, The 32nd National and the 1st International Geosciences Congress, Uremia, Iran. 
[99] Fakhri, M., Eslamian, S. S., Rostamian, R., and Fazeli, I, 2012, A Review on Erosion and Sediment Transfer Models with Emphasis on Sediment Modeling of Beheshtabad Sub-basin, North Karoon, using SWAT Model, Ninth International Conference on River Engineering, Ahvaz.

[100]Eslamian, S. S. and S. A. Gohari, 2006, Investigation of Flooding Process in South-Esfahan Basin, International Congress of Islamic World Geographers, Esfahan University, Isfahan.

[101]Eslamian, S. S., Ghoudarzi, A. and R. Nazari, 2006, Investigation of the Changes of Permeability, Physical and Chemical Characteristics of Sediment Basins for Artificial Recharge in Bagh-E-Sorkh Region, Shahreza, Isfahan, 22nd Annual International Conference on Soils, Sediments and Water, University of Massachusetts at Amherst, USA.

[102] Saadati, S., Soltani-Koupai, S. and S. S. Eslamian, 2006, Frequency Analysis of Meteorological Drought Using Standard Precipitation Index (SPI) In Zayanderud Basin, First Regional Conference on Optimum Utilization of Water Resources in the Karun and Zayanderud Rivers Basins, Shahrekord University, 167.

[103]Keshavarzy, A., Erskine W. D. and S. S. Eslamian, 1995, River Management Vs. Urban Development in the Hawkesbury-Nepean River Basin, Australia, Regional Conference on Water Resources Management, Isfahan University of Technology, Isfahan, Iran, 629-637.

[104]Eslamian, S. and F. Eslamian, 2017, Handbook of Drought and Water Scarcity, Vol. 1: Principles of Drought and Water Scarcity, Francis and Taylor, CRC Group, USA, 660 Pages.

[105]Eslamian, S. and F. Eslamian, 2017, Handbook of Drought and Water Scarcity, Vol. 2: Environmental Impacts and Analysis of Drought and Water Scarcity, Francis and Taylor, CRC Group, USA, 680 Pages.

[106]Eslamian, S. and F. Eslamian, 2017, Handbook of Drought and Water Scarcity, Vol. 3: Management of Drought and Water Scarcity, Francis and Taylor, CRC Group, USA, 645. Pages.

[107]Angelakis, A. N., Chiotis, E., Eslamian, S., Weingartner, H., 2017, Underground Aqueducts Handbook, Taylor and Francis Group, CRC Press, USA, 511 Pages.

[108]Zalewski, M., McClain, M. E., and Eslamian, S., 2016, New Challenges and Dimensions of Ecohydrology, Part II Ecohydrology and Hydrobiology, Special Issue, Volume 16, Issue 2, Pages 71-124, Elsevier.

[109]Zalewski, M., McClain, M. E., and Eslamian, S., 2016, New Challenges and Dimensions of Ecohydrology, Part I, Ecohydrology and Hydrobiology, Special Issue, Volume 16, Issue 1, Pages 1-70, Elsevier.

[110]Godarzi, A., Eslamian, S., Ostad-Ali-Askari, K., 2016, Water in Literature Aspects: Social and Cultural Aspects, Nashreshahr, 135 Pages.

[111]Eslamian, S., Ostad-Ali-Askari, K., Salehi, M., Agha-Esmaeli, M., Sadeghi, M., Navabpour, B., MohriEsfahani, E., Mousavi-Madani, M., Zad-Bagher-Seighalani, E., Sadri, A., Shirvani-Dastgerdi, H. R., 2016, Engineering Operations Research: Linear Planning, Optimization and Genetic Algorithm, Kankash, 126 Pages.

[112]Eslamian, S., Ostad-Ali-Askari, K., Shayannejad, M., Ghasemi-Zeniani, M., Marzi-Nohadani, M., Heidari, F., Mohri-Esfahani, E., Haeri-Hamadani, M., 2016., Groundwater Hydrodynamic, Horoufchin, 193 Pages.

[113]Ostad-Ali-Askari, K., Shayannejad, M., Eslamian, S., Jahangiri, A. A., Shabani, A. H., 2016, Environmental Hydraulics of Open Channel Flows, Kankash, 332 Pages.

[114]Eslamian, S. S. and R. Mirabbasi, 2017, Application of Statistical Methods in Water Sciences, Aeij Publishing, Tehran, Iran, Under Press.

[115]Eslamian, S, 2015, (ed.) Urban Water Reuse Handbook, Francis and Taylor, CRC Group, USA, 1141 Pages.

[116]Eslamian, S., 2014, (ed.) Handbook of Engineering Hydrology, Vol. 1: Fundamentals and Applications, Taylor and Francis, CRC Group, USA, 636 Pages.

[117]Eslamian, S., 2014, (ed.) Handbook of Engineering Hydrology, Vol. 2: Modeling, Climate Change and Variability, Taylor and Francis, CRC Group, USA, 646 Pages.

[118]Eslamian, S., 2014, (ed.) Handbook of Engineering Hydrology, Vol. 3: Environmental Hydrology and Water Management, Taylor and Francis, CRC Group, USA, 606 Pages.

[119]Eslamian, S. S., 2013, Groundwater and Surface Water Interaction (GSWI): 3: Unconvenntional Groundwater, International Journal of Water, Special Issue Volume, Indersciences, Vol. 7, No. 1/2, 1-141.

[120]Eslamian, S. S., 2011, Groundwater and Surface Water Interaction (GSWI): 2. Case Studies, International Journal of Water, Special Issue Volume, Indersciences, Vol. 6, No. 1, 1-136.

[121]Eslamian, S. S., and S. Tarkesh Esfahani, 2011, Water Reuse (Urban Waste Water Application), Arkan Danesh Publishing, Isfahan, Iran, 327 Pages.

[122]Sharifani, M. M. and S. S. Eslamian, 2010, Humid Region Fruit Trees, Aeij Publishing, Tehran, Iran. 
[123]Eslamian, S. S., 2009, Basin Ecology and Environment (BEE), International Journal of Ecological Economic \& Statistics, Ed., Special Issue Volume, CESER, Vol. 13, No. W09, 1-99.

Citation: Dr. K. O. A. Askari, "Using SWAT Model to Determine Runoff, Sediment Yield in Maroon-Dam Catchment", International Journal of Research Studies in Agricultural Sciences, vol. 3, no. 12, p. 31-41, 2017. http://dx.doi.org/10.20431/2454-6224.0312004

Copyright: (C) 2017 Authors. This is an open-access article distributed under the terms of the Creative Commons Attribution License, which permits unrestricted use, distribution, and reproduction in any medium, provided the original author and source are credited. 